Web Jurnal:

http://ejournal.kemenperin.go.id/jli

\title{
Produksi karbon aktif arang tempurung kelapa menggunakan kombinasi metode aktivasi secara kimia dan steam tekanan rendah
}

\section{Production of activated carbon from coconut shell charcoal using a combination method of chemical activation and low pressure steam}

\author{
Ahmad Muhajir ${ }^{1}$, Izarul Machdar*², dan Mariana ${ }^{2}$ \\ 1 Magister Teknik Kimia, Universitas Syiah Kuala, Banda Aceh 23111, Indonesia \\ 2 Jurusan Teknik Kimia, Universitas Syiah Kuala, Banda Aceh 23111,Indonesia \\ * e-mail: machdar@unsyiah.ac.id
}

\begin{tabular}{l}
\hline INFO ARTIKEL \\
\hline Sejarah artikel: \\
Diterima : \\
1 Juli 2021 \\
Direvisi : \\
29 November 2021 \\
Diterbitkan : \\
30 Desember 2021
\end{tabular}

Kata kunci:

karbon aktif;

arang tempurung

kelapa;

aktifasi kimia;

steam tekanan rendah

\begin{abstract}
ABSTRAK
Arang dapat diubah menjadi karbon aktif melalui tahapan aktivasi, yang mana proses ini dapat dilakukan secara kimia maupun fisika, dengan tujuan memperbesar ukuran porinya. Pada paper ini telah dikaji mengenai karakteristik karbon aktif dari arang tempurung kelapa yang diaktivasi menggunakan metode kombinasi aktivasi kimia dan steam tekanan rendah. Arang tempurung kelapa yang digunakan berasal dari pengrajin di Desa Teubang Phui. Arang diaktivasi secara kimia dengan cara direndam dalam larutan Asam Fosfat $\left(\mathrm{H}_{3} \mathrm{PO}_{4}\right) 60 \%, 70 \%$, dan 80\%, dengan lama waktu aktivasi 1, 2, dan 3 hari. Karakterisasi karbon aktif meliputi uji kadar air, kadar zat menguap, kadar abu total, kadar karbon menunjukan nilai rata-rata yaitu berturut-turut $0,04 \% ; 3,02 \% ; 3,02 \%$; dan 93,96\%. Aktivasi karbon dilanjutkan dengan disteam pada suhu $100^{\circ} \mathrm{C}$ selama 4 jam. Hasil uji daya serap iodin menunjukan peningkatan berkisar antara 3-12\% dari sebelum disteam. Semua parameter memenuhi syarat baku mutu karbon aktif menurut SNI 063730-95, kecuali bilangan iod yang nilainya $<200 \mathrm{mg} / \mathrm{g}$. Spektrum FTIR tidak menunjukan perbedaan gugus fungsi antara sebelum dan sesudah aktivasi arang tempurung kelapa. Luas permukaan karbon aktif yang teraktivasi dengan $\mathrm{H}_{3} \mathrm{PO}_{4} 60 \%$, perendaman 1 hari, serta disteam, yaitu $23,235 \mathrm{~m}^{2} / \mathrm{g}$.
\end{abstract}

\begin{abstract}
Charcoal can be converted into activated carbon through an activation step, where this process can be carried out chemically or physically, to increase the pore size. In this paper, we have studied the characteristics of activated carbon from coconut shell charcoal which was activated using a combination method of chemical activation and low-pressure steam. The coconut shell charcoal used comes from craftsmen at Teubang Phui. Charcoal was chemically activated by immersion in 60\%, 70\%, and 80\% phosphoric acid $\left(\mathrm{H}_{3} \mathrm{PO}_{4}\right)$ solutions, with activation times of 1,2 , and 3 days. Characterization of activated carbon includes tests for water content, volatile matter content, total ash content, carbon content showing an average value of $0.04 \%$; $3.02 \%$; $3.02 \% ; 93.96 \%$, respectively. Carbon activation was continued by steaming at $100^{\circ} \mathrm{C}$ for 4 hours. The results of the iodine absorption test showed an increase between 3-12\% from before steaming. All parameters meet the quality standard requirements for activated carbon according to SNI 063730-95, except for the iodine number, whose value is $<200 \mathrm{mg} / \mathrm{g}$. The FTIR spectrum did not show any difference in functional groups between before and after activation of coconut shell charcoal. The surface area of activated carbon activated with $60 \% \mathrm{H}_{3} \mathrm{PO}_{4}, 1$-day immersion, and steam, was 23.235 $m^{2} / g$.
\end{abstract}




\section{Pendahuluan}

Tanaman kelapa (Cocus nucifera. L) merupakan tanaman yang tumbuh subur di Indonesia. Data statistik menunjukkan jumlah produksi kelapa di Provinsi Aceh mencapai 63.772 ton pada tahun 2019, dan diperkirakan terus naik hingga $0,43 \%$ per tahunnya (Kementan RI, 2019). Semakin tinggi produksi kelapa, tentu berimbas kepada banyaknya produk samping yang dihasilkan yaitu berupa tempurung dan sabut kelapa.

Di beberapa daerah tempurung kelapa dimanfaatkan sebagai bahan kerajinan tangan. Selain itu telah banyak penelitian yang menggunakan tempurung kelapa untuk memproduksi briket (Budi, 2017), filler papan komposit (Zohri et al., 2013), aditif membran keramik (Apriyanti and Subekti, 2019), dan yang paling umum yaitu karbon aktif (Nustini and Allwar, 2019; Packialakshmi et al., 2021; Widiyastuti et al., 2020). Di Kabupaten Aceh Besar, tempurung kelapa diproses menjadi arang kelapa dan dipasarkan dengan harga yang cukup rendah. Hingga saat ini pengrajin hanya memproduksi arang kelapa sebagai bahan baku pembuatan briket.

Idealnya arang tempurung kelapa dapat diproduksi menjadi karbon aktif, dikarenakan kandungan lignin dan selulosa yang tinggi sehingga memiliki sifat difusi termal yang baik (Zamhari et al., 2021). Proses yang perlu dilakukan untuk mengubah arang tempurung kelapa menjadi karbon aktif ialah aktivasi. Melalui proses tersebut, ukuran pori karbon diperbesar baik dengan metode kimia dan fisika. Aktivasi secara kimia dilakukan dengan menggunakan senyawa kimia, sedangkan aktivasi fisika dengan menguapkan atau memanaskan karbon (Jamilatun et al., 2016).

Pada aktivasi secara kimia, karbon direndam dalam bahan kimia tertentu seperti $\mathrm{ZnCl}_{2}, \mathrm{NaOH}, \mathrm{KOH}, \mathrm{H}_{2} \mathrm{SO}_{4}$, dan $\mathrm{H}_{3} \mathrm{PO}_{4}$. (Lestari et al., 2016) telah berhasil mengaktifasi arang tempurung kelapa dengan menggunakan aktivator $\mathrm{H}_{3} \mathrm{PO}_{4} \quad 8 \%$. Hasil penelitian menunjukan karakteristik karbon sesuai dengan SNI 06$3730-95$, dengan luas permukaan $61,82 \mathrm{~m}^{2} / \mathrm{g}$. Pada proses aktivasi secara fisika, umumnya metode yang digunakan adalah steam bertemperatur tinggi (400$1000^{\circ} \mathrm{C}$ ) (Bakti \& Gareso, 2018). Proses ini bertujuan untuk menghilangkan sebagian besar bahan volatil dan mengaktivasi arang dengan agen pengaktif, seperti $\mathrm{CO}_{2}$, uap, dan udara, sehingga menghasilkan pelepasan oksida karbon dari permukaan arang (Zhou et al., 2018).

Keuntungan utama dari aktivasi fisik adalah tidak adanya zat pengotor yang berasal dari agen pengaktif kimia. Sebaliknya, pada aktivasi fisik menggunakan steam temperatur tinggi dibutuhkan energi panas yang sangat besar sehingga berdampak pada biaya produksi yang tinggi (Kong et al., 2018). Oleh karena itu perlu adanya penelitian tentang penggunaan steam bertekanan rendah sehingga dapat dijadikan pertimbangan untuk proses aktivasi yang lebih ekonomis.

Berdasarkan studi literatur, kombinasi metode aktivasi kimia dan steam tekanan rendah masih sedikit dilaporkan. Oleh karena itu, pada paper ini telah dikaji mengenai karakteristik karbon aktif dari arang tempurung kelapa yang diaktifasi menggunakan metode kombinasi. Karbon aktif yang diproduksi kemudian dibandingkan dengan standar baku mutu SNI 06-373095.

\section{Metode \\ 2.1 Waktu dan tempat}

Penelitian ini telah dikerjakan pada bulan Februari April 2021. Kegiatan utama seperti preparasi bahan, aktivasi karbon aktif, uji kadar air, kadar zat menguap, kadar abu total, kadar karbon, dan daya serap iodin dilakukan diLaboratorium Kimia Dasar, Jurusan Teknik Kimia, Universitas Syiah Kuala. Sedangkan beberapa uji lainnya seperti Brunauer-Emmett-Teller (BET) dan Fourier Transform Infrared (FTIR) dikirim sampel ke beberapa Laboratorium diantaranya Lab. Fisika LIPI, Jakarta dan Lab. Teknik Penguji Kualitas Lingkungan, Teknik Kimia USK.

\subsection{Bahan dan alat}

Bahan kimia yang digunakan dalam penelitian ini diantaranya Iodin $\left(\mathrm{I}_{2}\right)$ (konsentrasi $99,8 \%$, grade pro analysis, merek merck Jerman), sodium thiosulfate pentahydrate $\left(\mathrm{Na}_{2} \mathrm{~S}_{2} \mathrm{O}_{3}\right)$ (kemurnian $98 \%$, grade pro analysi, merek Merck Jerman), asam fosfat $\left(\mathrm{H}_{3} \mathrm{PO}_{4}\right)$ (Pekat 85\%, grade teknis), dan amilum (grade pro analysi, merek Merck Jerman). Arang tempurung kelapa diperoleh dari pengrajin kecil di Desa Teubang Phui, Kecamatan Ingin Jaya, Kabupaten Aceh Besar. Akuades digunakan untuk membuat larutan dan pencuci karbon aktif. Semua bahan kimia digunakan tanpa melalui proses pemurnian.

Alat yang digunakan diantaranya kertas saring, ayakan mesh, $\mathrm{pH}$ meter, timbangan analitik, cawan porselin, oven, desikator, labu erlenmeyer, pipet volume, pipet mikro, gelas ukur, gelas kimia, buret, statif, batang pengaduk, pengaduk magnetik, corong, hotplate, botol semprot, dan alat steam. Instrumen analisis menggunakan Brunauer-Emmett-Teller (BET) (BET Surface Area and Pore Size Analyzer, Brand/ Type: Quantachrome Nova 4200e) dan Fourier Transform Infrared (FTIR) (Shimadzu IRPrestige-21 SN A210048 02668).

\subsection{Preparasi bahan baku}

Arang tempurung kelapa dihaluskan dan diayak dengan ayakan ukuran 8 dan 12 mesh sehingga diperoleh butiran karbon dengan ukuran diantara keduanya $(2,3-$ $1,6 \mathrm{~mm})$.

\subsection{Proses aktivasi karbon secara kimia dan fisika}

Arang yang telah diayak kemudian ditempatkan ke dalam 3 buah erlenmeyer masing-masing sebanyak 40 gr. Kemudian ditambahkan $150 \mathrm{~mL} \quad \mathrm{H}_{3} \mathrm{PO}_{4}$ dengan konsentrasi larutan setiap Erlenmeyer yaitu 60\%, 70\%, dan $80 \%$. Campuran diaduk di atas pengaduk magnetik pada temperatur ruang, lalu didiamkan dengan variasi waktu 1, 2, dan 3 hari. Kemudian karbon dicuci dengan aquades hingga diperoleh $\mathrm{pH}$ netral, lalu dipisahkan dengan kertas saring. Lalu karbon aktif dikeringkan di dalam oven pada temperatur $105^{\circ} \mathrm{C}$ selama 1 jam. 
Pada tahap akhir dilanjutkan dengan aktivasi secara fisika yaitu dengan steam bertekanan rendah (1,013 bar). Karbon dimasukan ke dalam alat steam bertemperatur $100^{\circ} \mathrm{C}$ selama 4 jam. Kabon tersebut kemudian dikeringkan kembali di dalam oven selama 2 jam pada temperatur $105^{\circ} \mathrm{C}$. Alur penelitian ini secara ringkas dapat dilihat pada Gambar 1.

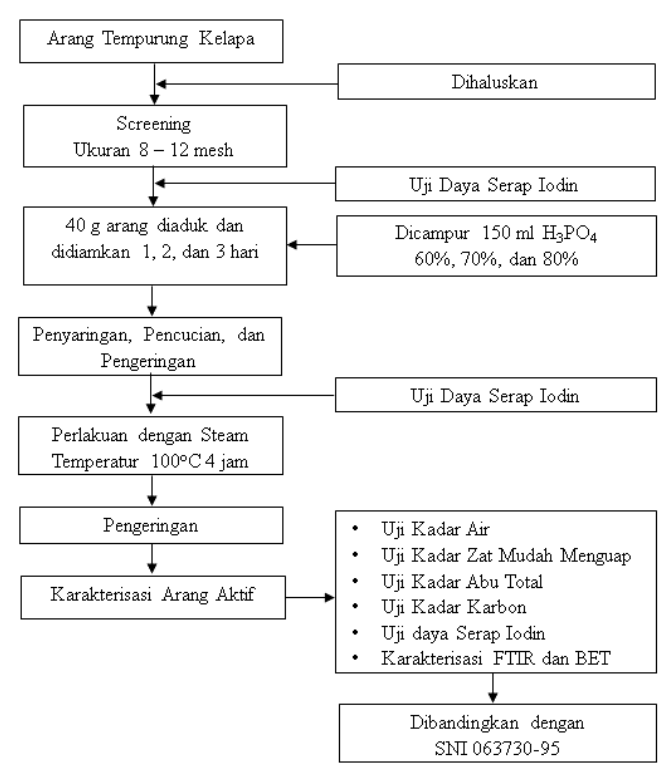

Gambar 1. Skema penelitian

\subsection{Karakterisasi karbon aktif 2.5.1 Kadar air}

Karbon aktif diambil sebanyak 1 gr, kemudian dikeringkan di dalam oven dengan temperatur $105^{\circ} \mathrm{C}$. Pengeringan terus belanjut hingga diperoleh massa karbon konstan, lalu karbon tersebut didinginkan di dalam desikator. Persentase kadar air dihitung menggunakan persamaan 1 .

Kadar airr $(\%)=\frac{\text { bobot contoh awal }- \text { bobot contoh akhir }}{\text { bobot contoh awal }} \mathrm{x} 100 \%$

\subsubsection{Kadar zat mudah menguap (volatiles)}

Pengujian ini dilakukan dengan menempatkan karbon aktif di dalam furnace dengan temperatur $900^{\circ} \mathrm{C}$ selama 15 menit. Kemudian didinginkan di dalam desikator hingga temperatur ruang. Persentase kadar zat mudah menguap dihitung menggunakan persamaan 2 .

Kadar volatiles $(\%)=\frac{\text { bobot contoh yang hilang }}{\text { bobot contoh awal }} \times 100 \%$

\subsubsection{Kadar abu total}

Diambil 1 gr karbon aktif, lalu dikeringkan dalam oven (temperatur $105^{\circ} \mathrm{C}$ ) hingga dicapai massa konstan. Karbon tersebut kemudian dipanaskan di dalam furnace bertemperatur $650^{\circ} \mathrm{C}$ selama 4 jam. Sebelum ditimbang, karbon terlebih dahulu didinginkan di dalam desikator.
Perhitungan persentase abu total diperoleh dengan menggunakan persamaan 3 .

Kadar abu $(\%)=\frac{\text { bobot contoh sisa }}{\text { bobot contoh awal }} \times 100 \%$

\subsubsection{Kadar karbon}

Kadar karbon merupakan selisih dari persentase total dengan jumlah persentase kadar abu ditambah kadar zat mudah menguap (volatiles). Secara matematis dihitung dengan persamaan 4 .

Kadar karbon $(\$ 6)=100 \%-(\$ 6$ Kadar abu $\$ \$ 6$ Kadar volatiles

\subsubsection{Daya serap iodin}

Uji daya serap iodin bertujuan untuk mengidentifikasi kemampuan adsorbsi karbon aktif yang diproduksi. Pengujian ini diawali dengan mencampurkan 1 gr karbon aktif dengan $25 \mathrm{~mL}$ larutan iodin $0,125 \mathrm{~N}$ di dalam erlenmeyer. Campuran tersebut kemudian diaduk selama 15 menit dan disimpan di lemari gelap selama 2 jam. Kemudian campuran dipisahkan dengan kertas saring dan diambil filtratnya sebanyak $10 \mathrm{~mL}$ untuk dititrasi. Filtrat dititrasi dengan larutan $\mathrm{Na}_{2} \mathrm{~S}_{2} \mathrm{O}_{3} \quad 0,1 \mathrm{~N}$ hingga muncul warna kuning muda. Indikator amilum ditambahkan sebanyak $1 \mathrm{~mL}$, lalu dilanjutkan mentitrasi fitrat sampai warna biru tepat hilang. Volume larutan $\mathrm{Na}_{2} \mathrm{~S}_{2} \mathrm{O}_{3}$ yang digunakan tersebut dicatat dan menjadi nilai penting dalam perhitungan daya serap iodin. Seluruh rangkaian uji ini merupakan metode titrasi iodometri dan hasil perhitungan sering disebut bilangan iod. Bilangan iod dapat dihitung dengan menggunakan persamaan 5 .

$$
\begin{aligned}
& \mathrm{BI}=\frac{25}{5} \times \frac{(\text { Vol. titrasi blanko }- \text { Vol titrasi bahan) } x \text { Be iod } x W}{\text { Berat Karbon Aktif }(W)} \\
& \text { BI = daya serap iodin }(\mathrm{mg} / \mathrm{g}) \\
& \text { Be iod }=12,69 \\
& \mathrm{~N}=\text { Normalitas } \mathrm{Na}_{2} \mathrm{~S}_{2} \mathrm{O}_{3}(\mathrm{~N}) \\
& \mathrm{W}=\text { berat karbon aktif (gr) }
\end{aligned}
$$

\subsubsection{Analisa luas permukaan, dan gugus fungsi}

Pengujian luas permukaan arang aktif digunakan metode Brunauer-Emmett-Teller (BET). Analisis ini bertujuan untuk menentukan luas permukaan arang aktif. Luas yang dimaksud merupakan luasan yang dapat diisi oleh molekul adsorbat. Sedangkan analisis gugus fungsi digunakan instrumen Fourier Transform Infrared (FTIR). Alat yang digunakan yaitu Shimadzu IRPrestige-21 dalam range $4000 \mathrm{~cm}^{-1}$ hingga $400 \mathrm{~cm}^{-1}$ dengan suhu ruang. Sebelum dianalisis sampel digiling bersamaan dengan $\mathrm{KBr}$, dengan perbandingan rasio 1:9 (sampel : KBr).

\section{Hasil dan Pembahasan 3.1 Proses aktivasi}

Aktivasi berfungsi untuk memperbesar ukuran pori yang sudah terbentuk pada saat proses karbonisasi serta 
membentuk pori-pori baru. Pada paper ini, proses aktivasi kimia dilakukan dengan merendam arang tempurung kelapa ke dalam larutan $\mathrm{H}_{3} \mathrm{PO}_{4}$ dengan variasi konsentrasi $60 \%, 70 \%$, dan $80 \%$ dan waktu perendaman 1, 2, dan 3 hari. Tujuan dari perlakuan variasi konsentrasi dan waktu aktvasi yaitu untuk mengetahui pengaruhnya terhadap karakteristik karbon aktif yang diproduksi.

Tabel 1 menunjukkan bahwa proses aktivasi karbon aktif menyebabkan pengurangan massa sekitar $14 \%$. Pengurangan massa tersebut terjadi akibat pengeluaran unsur-unsur seperti tar, hidroarang serta unsur lain yang masih tersisa pada arang tempurung kelapa. Pada tahapan pencucian dan penyaringan karbon yang dilakukan berulang kali juga menyebabkan ada sebagian material yang terlarut atau terbuang selama proses ini.
Pengurangan massa karbon setelah aktivasi pada setiap variasi konsentrasi $\mathrm{H}_{3} \mathrm{PO}_{4}$ dan waktu aktivasi tidak signifikan. Hal ini menunjukan bahwa kedua variasi tersebut tidak mempengaruhi berat massa karbon aktif yang diproduksi. Pengurangan massa terbesar yaitu 6,95 g diperoleh pada variasi konsentrasi $\mathrm{H}_{3} \mathrm{PO}_{4} 80 \%$ dan waktu aktivasi 3 hari.

\subsection{Karakteristik karbon aktif}

Perbedaan konsentrasi $\mathrm{H}_{3} \mathrm{PO}_{4}$ dan waktu aktivasi akan mempengaruhi karakteristik dari karbon aktif yang diproduksi. Karakteristik yang teramati pada penelitian ini diantaranya kadar air, kadar abu, kadar zat menguap, kadar arang terikat dan bilangan iodin, semua parameter terangkum dalam Tabel 2.

Tabel 1.

Pengurangan massa karbon setelah proses aktivasi kimia

\begin{tabular}{lllll}
\hline \multirow{2}{*}{$\begin{array}{l}\text { Konsentrasi } \mathrm{H}_{3} \mathrm{PO}_{4} \\
(\%)\end{array}$} & Waktu Aktivasi (hari) & \multicolumn{2}{l}{ Massa Karbon } \\
\cline { 3 - 5 } & & Awal $(\mathrm{g})$ & Akhir $(\mathrm{g})$ & Pengurangan $(\mathrm{g})$ \\
\hline \multirow{2}{*}{60} & 1 & 40 & 33,70 & 6,30 \\
& 2 & 40 & 33,98 & 6,02 \\
& 3 & 40 & 33,83 & 6,17 \\
70 & 1 & 40 & 34,69 & 5,31 \\
& 2 & 40 & 34,45 & 5,55 \\
80 & 3 & 40 & 36,79 & 3,21 \\
& 1 & 40 & 34,03 & 5,97 \\
& 2 & 40 & 33,45 & 6,55 \\
\end{tabular}

Tabel 2.

Hasil perhitungan karakteristik karbon aktif

\begin{tabular}{|c|c|c|c|c|c|c|c|c|}
\hline \multirow{3}{*}{$\begin{array}{l}\text { Konsentrasi } \\
\mathrm{H}_{3} \mathrm{PO}_{4}(\%)\end{array}$} & \multirow{3}{*}{$\begin{array}{l}\text { Waktu } \\
\text { Aktivasi } \\
\text { (hari) }\end{array}$} & \multirow{3}{*}{$\begin{array}{l}\text { Kadar Air } \\
(\%)\end{array}$} & \multirow{3}{*}{$\begin{array}{l}\text { Kadar } \\
\text { Abu }(\%)\end{array}$} & \multirow{3}{*}{$\begin{array}{l}\text { Kadar Zat } \\
\text { Menguap } \\
(\%)\end{array}$} & \multirow{3}{*}{$\begin{array}{l}\text { Kadar Karbon } \\
(\%)\end{array}$} & \multicolumn{3}{|c|}{ Daya serap iodin (mg/g) } \\
\hline & & & & & & \multirow[b]{2}{*}{ Arang } & \multicolumn{2}{|c|}{ Karbon Aktif } \\
\hline & & & & & & & $\begin{array}{l}\text { Sebelum } \\
\text { Steam }\end{array}$ & $\begin{array}{l}\text { Setelah } \\
\text { Steam }\end{array}$ \\
\hline & & & & & & 123,74 & & \\
\hline \multirow{4}{*}{60} & 1 & 0,0479 & 4,07 & 3,99 & 91,94 & & 158,64 & 171,33 \\
\hline & 2 & 0,0270 & 2,79 & 2,83 & 94,38 & & 163,08 & 164,98 \\
\hline & 3 & 0,0339 & 2,91 & 2,89 & 94,20 & & 164,98 & 166,25 \\
\hline & 1 & 0,0416 & 2,78 & 2,76 & 94,46 & & 152,29 & 153,56 \\
\hline \multirow[t]{3}{*}{70} & 2 & 0,0376 & 2,49 & 2,49 & 95,02 & & 144,04 & 155,46 \\
\hline & 3 & 0,0355 & 3,07 & 3,04 & 93,90 & & 156,73 & 161,81 \\
\hline & 1 & 0,0483 & 2,95 & 3,01 & 94,04 & & 139,60 & 144,68 \\
\hline \multirow[t]{2}{*}{80} & 2 & 0,0401 & 2,71 & 2,71 & 94,58 & & 145,95 & 145,95 \\
\hline & 3 & 0,0323 & 3,41 & 3,50 & 93,09 & & 149,12 & 152,29 \\
\hline
\end{tabular}

\subsubsection{Kadar Air}

Keberadaan air di dalam karbon berhubungan dengan sifat higroskopis, yang artinya karbon aktif memiliki afinitas tinggi dengan air. Oleh karena sifat tersebut, karbon aktif dapat digunakan sebagai adsorben. Gravimetri merupakan metode analisis dengan cara menghitung berat konstan bahan setelah dikeringkan, dalam hal ini air yang diuapkan terlebih dahulu.

Penentuan kadar air dilakukan dengan memanaskan karbon aktif di dalam oven bertemperatur $105^{\circ} \mathrm{C}$ selama 3 jam, dengan tujuan untuk memaksimalkan dehidrasi karbon. Pada pengujian ini, diasumsikan bahwa di dalam karbon aktif hanya mengandung air yang mudah menguap. Kandungan air yang terjebak dalam rongga akan menutupi pori-pori karbon aktif. Semakin rendah kadar air maka akan semakin banyak pori yang dapat ditempati oleh molekul iodin (Laos and Selan, 2016).

Berdasarkan Tabel 2 diketahui bahwa kadar air untuk setiap konsentrasi dan waktu aktivasi memiliki perbedaan persentase yang tidak signifikan dengan nilai rata-rata $0,04 \%$. Hal ini menunjukan bahwa antar variasi konsentrasi dan waktu aktivasi tidak mempengaruhi kadar air karbon aktif. Nilai ini lebih baik dari penelitian Aryani et al., (2019) sebesar 6\% dan memenuhi syarat baku mutu karbon aktif menurut SNI 06-3730-95 (maksimal 15\%). 


\subsubsection{Kadar abu}

Persen kadar abu mengidentifkasikan kandungan oksida logam yang mungkin masih terdapat dalam karbon aktif. Oksida logam tersebut dapat berupa silikon, sulfur, kalsium, maupun logam lain yang jumlahnya kecil. Kadar abu yang tinggi mempengaruhi kualitas karbon aktif saat diaplikasikan sebagai adsorben (Jamilatun and Setyawan, 2014). Pengujian kadar abu dilakukan dengan menempatkan karbon aktif ke dalam furnace bertemperatur $650^{\circ} \mathrm{C}$ selama 4 jam. Hasil yang diperoleh adalah abu berupa oksida-oksida logam yang terdiri dari mineral yang tidak dapat menguap pada proses pengabuan.

Berdasarkan Tabel 2 diketahui bahwa kadar air untuk setiap konsentrasi dan waktu aktivasi memiliki perbedaan persentase yang tidak signifikan dengan nilai rata-rata $3,02 \%$. Persentase kadar abu tertinggi diperoleh pada konsentrasi $\mathrm{H}_{3} \mathrm{PO}_{4} 60 \%$ dan waktu aktivasi 1 hari, yaitu $4,07 \%$ di mana nilai tersebut sesuai dengan penelitian (Aryani et al., 2019) yaitu berkisar 4,27\%. Nilai kadar abu untuk semua karbon aktif telah memenuhi standar yang telah ditetapkan SNI 06-373095, yaitu maksimal $10 \%$.

\subsubsection{Kadar zat menguap}

Persen kadar zat yang menguap mengindikasikan jumlah senyawa yang belum menguap pada proses karbonisasi dan aktivasi, namun menguap pada suhu $900^{\circ} \mathrm{C}$. Kemampuan daya serap karbon aktif dipengaruhi oleh besarnya kadar zat menguap, yang mana bila nilai tersebut terlalu tinggi, akan mengurangi daya serapnya (Jamilatun and Setyawan, 2014).

Berdasarkan Tabel 2 diketahui bahwa kadar zat menguap untuk setiap konsentrasi dan waktu aktivasi memiliki perbedaan persentase yang tidak signifikan dengan nilai rata-rata $3,02 \%$. Nilai tersebut telah jauh memenuhi syarat baku mutu karbon aktif menurut SNI 06-3730-95, yaitu maksimal 25\% dan lebih baik dari penelitian Aryani et al., (2019) sebesar 37,03\%.

\subsubsection{Kadar karbon}

Kadar karbon dihitung dengan tujuan untuk mengidentifikasi karbon yang masih terkandung setelah melalui tahapan karbonisasi dan aktivasi. Kadar karbon yang tinggi sangat diharapkan sebagai karbon aktif (Siahaan et al., 2013).

Tabel 2 menunjukkan bahwa persentase kadar karbon yang diperoleh dari proses aktivasi kimia sangat tinggi yaitu rata-rata $93,96 \%$, yang mana nilai tersebut jauh lebih tinggi dari standar SNI 06-3730-95 yaitu minimal $65 \%$.

\subsubsection{Daya serap karbon aktif terhadap iodin}

Daya serap iodin menggambarkan kapasitas karbon aktif dalam mengadorpsi komponen dengan berat molekul rendah. Besarnya jumlah mg iodin yang mampu diserap oleh 1 gr karbon aktif disebut bilangan iod. Merujuk pada standar baku karbon aktif menurut SNI 06-3730-1995, bilangan iod setidaknya memiliki nilai minimum $200 \mathrm{mg} / \mathrm{g}$. Karbon aktif yang memiliki bilangan iod tinggi mengidentifikasi bahwa luas permukaan dan struktur mikro yang lebih besar.

Pada Tabel 2 menunjukkan daya serap iodin arang tempurung kelapa sebesar 123,74 mg/g, kemudian meningkat nilainya setelah dilakukan aktivasi menjadi karbon aktif. Hal ini disebabkan karena luas permukaan aktif yang lebih besar akibat dari proses aktivasi. Nilai daya serap iodin karbon aktif yang diaktivasi dengan $\mathrm{H}_{3} \mathrm{PO}_{4}$ berkisar antara 139,60-164,98 mg/g. Bilangan iod terbesar diperoleh pada karbon aktif yang direndam $\mathrm{H}_{3} \mathrm{PO}_{4} 60 \%$ dan waktu aktivasi 3 hari, yaitu 164,98 $\mathrm{mg} / \mathrm{g}$. Penambahan konsentrasi $\mathrm{H}_{3} \mathrm{PO}_{4}$ hingga $80 \%$, menyebabkan penurunan bilangan iod. Hal ini terjadi karena adanya senyawa $\mathrm{H}_{3} \mathrm{PO}_{4}$ yang terjebak di dalam pori karbon aktif.

Penambahan perlakuan dengan steam temperatur $100^{\circ} \mathrm{C}$ selama 4 jam cukup meningkatkan bilangan iodin yaitu berkisar antara 3-12\% dari sebelum disteam (Tabel 2). Hal ini disebabkan karena temperatur dan waktu yang digunakan masih belum cukup untuk meningkatkan ukuran pori karbon. Bilangan iodin terbaik dihasilkan pada karbon aktif dengan konsentrasi $\mathrm{H}_{3} \mathrm{PO}_{4} 60 \%$ waktu aktivasi 1 hari, yaitu sebesar $171,33 \mathrm{mg} / \mathrm{g}$ di mana hasil tersebut lebih rendah dari penelitian Jamilatun and Setyawan (2014) yang memakai suhu aktivasi $800^{\circ} \mathrm{C}$ sebesar $580 \mathrm{mg} / \mathrm{g}$. Semua karbon aktif yang diproduksi pada penelitian ini, memiliki bilangan iodin minimal 200 $\mathrm{mg} / \mathrm{g}$, yang artinya belum memenuhi standar SNI 063730-1995.

\subsubsection{Gugus fungsi karbon aktif}

Analisis FTIR digunakan untuk mengidentifikasi perubahan gugus fungsi karbon sebelum dan sesudah aktivasi dengan menggunakan larutan $\mathrm{H}_{3} \mathrm{PO}_{4}$. Spektrum FTIR karbon aktif dapat dilihat pada Gambar 2.

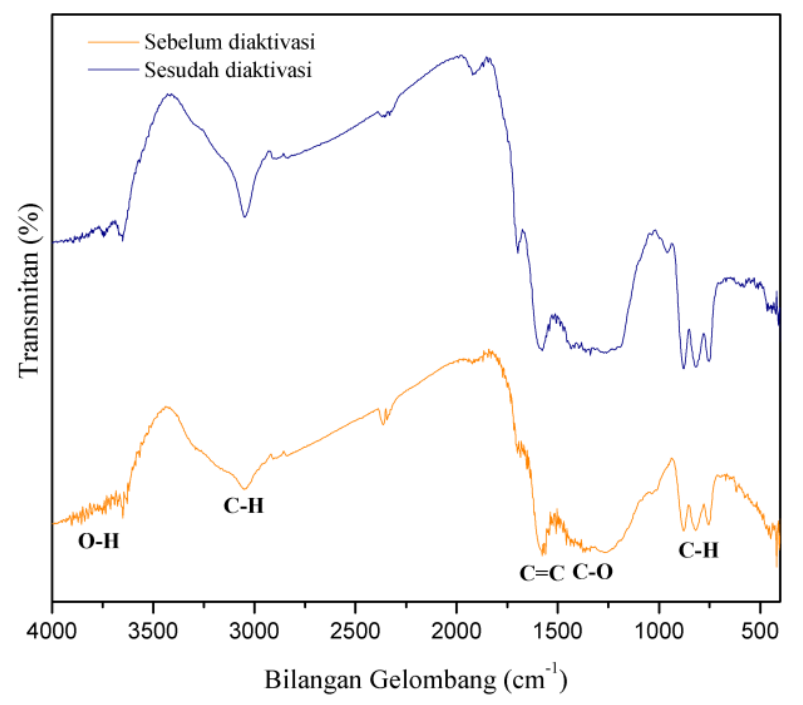

Gambar 2. Spektrum FTIR karbon sebelum dan sesudah diaktivasi

Hasil analisis gugus fungsi memperlihatkan bahwa arang tempurung kelapa sebelum aktivasi memiliki puncak $3049,46 \mathrm{~cm}^{-1}$ dan setelah aktivasi mengalami 
penurunan menjadi $3047,53 \mathrm{~cm}^{-1}$, puncak ini menunjukkan serapan dari gugus $\mathrm{C}-\mathrm{H}$ yang berada pada rentang 3100-3000 $\mathrm{cm}^{-1}$. Penurunan puncak dari gugus C-H pada arang aktif setelah aktivasi disebabkan karena lepasnya molekul air di dalam arang aktif. Hal ini membuktikan bahwa arang tempurung kelapa setelah aktivasi lebih bersih dari pengotor sehingga pori-pori arang akan lebih terbuka.

Selain itu pada rentang 3584-300 $\mathrm{cm}^{-1}$ dan $1310-1250$ $\mathrm{cm}^{-1}$ masing-masing merupakan gugus $\mathrm{O}-\mathrm{H}$ dan $\mathrm{C}-\mathrm{O}$. Munculnya kedua gugus tersebut mengindikasikan bahwa karbon aktif memiliki sifat polar (Wibowo et al., 2011). Dengan demikian karbon aktif yang diproduksi dapat diaplikasikan sebagai adsorben dalam proses penjernihan air. Pengujian FTIR pada arang teraktivasi $\mathrm{H}_{3} \mathrm{PO}_{4}$ menunjukkan munculnya gugus $\mathrm{C}-\mathrm{O}$ (alkohol/ eter/ ester/asam karboksilat) dan $\mathrm{C}-\mathrm{H}$ (alkana). Adanya gugus alkana pada permukaan arang disebabkan oleh gugus alkohol yang tereliminasi sebagian membentuk alkena pada saat aktivasi menggunakan asam fosfat. Pada puncak serapan dengan bilangan gelombang $1579,70 \mathrm{~cm}^{-1}$ menunjukkan keberadaan gugus $\mathrm{C}=\mathrm{C}$, yaitu selulosa dan hemiselulosa (Bani and Santjojo, 2013).

\subsubsection{Luas permukaan karbon aktif}

Metode Brunauer-Emmet-Teller (BET) digunakan untuk mengidentifikasi luas permukaan dari karbon aktif. Hasil uji BET dari sampel terbaik didapatkan luas permukaan spesifik untuk karbon aktif teraktivasi $\mathrm{H}_{3} \mathrm{PO}_{4}$ $60 \%$ perendaman selama 1 hari dan dilanjutkan dengan steam adalah $23,235 \mathrm{~m}^{2} / \mathrm{g}$. Hasil yang diperoleh cukup rendah, hal ini sesuai dengan hasil uji daya serap iodin yaitu $171.33 \mathrm{mg} / \mathrm{g}$, yang mana nilai tersebut lebih kecil dari standar baku karbon aktif menurut SNI 06-37301995 (minimal $200 \mathrm{mg} / \mathrm{g}$ ).

Penelitian sebelumnya melaporkan luas permukaan karbon aktif tempurung kelapa $61,82 \mathrm{~m}^{2} / \mathrm{g}$ pada konsentrasi $\mathrm{H}_{3} \mathrm{PO}_{4} 8 \%$ (Lestari et al., 2016). Penelitian lainnya dengan material yang sama namun menggunakan konsentrasi yang lebih tinggi $\left(\mathrm{H}_{3} \mathrm{PO}_{4} \quad 3 \mathrm{M}\right)$ yaitu $386.4470 \mathrm{~m}^{2} / \mathrm{g}$ (Kurniawan and Lutfi, 2014). Jika dibandingkan dengan hasil penelitian ini, luas permukaan karbon aktif yang diperoleh kecil, hal ini mungkin disebabkan karena proses karbonisasi yang berbeda (Hidayat et al., 2020).

\section{Kesimpulan}

Proses aktivasi karbon aktif menghasilkan pengurangan massa sekitar 14\%. Hasil karakterisasi karbon aktif meliputi uji kadar air, kadar zat menguap, kadar abu total, dan kadar karbon menunjukan nilai ratarata yaitu berturut-turut $0,04 \% ; 3,02 \% ; 3,02 \%$; dan 93,96\%. Penambahan perlakuan dengan steam temperatur $100^{\circ} \mathrm{C}$ selama 4 jam cukup meningkatkan bilangan iodin yaitu berkisar antara 3-12\% dari sebelum disteam. Analisis FTIR menunjukan bahwa baik sebelum dan sesudah aktivasi, arang tempurung kelapa memiliki kesamaan gugus kimia, yaitu $\mathrm{C}-\mathrm{H}, \mathrm{C}-\mathrm{O}, \mathrm{C}=\mathrm{C}$, dan $\mathrm{O}-\mathrm{H}$. Luas permukaan spesifik pada karbon aktif adalah $23,235 \mathrm{~m}^{2} / \mathrm{g}$.

\section{Daftar pustaka}

Apriyanti, E., Subekti, S., 2019. Pengembangan material komposit keramik dari abu terbang batubara dan kaolin clay aplikasi untuk pengolahan air bersih. Seminar Nasional Edusainstek, ISBN:2685-5852.

Aryani, F., Mardiana, F., \& Wartomo. (2019). Aplikasi metode aktivasi fisika dan aktivasi kimia pada pembuatan arang aktif dari tempurung kelapa (Cocos nucifera L). Indonesian Journal of Laboratory, 1(2), 16. https://doi.org/10.22146/ijl.v1i2.44743

Bakti, A. I., \& Gareso, P. L. 2018. Characterization of active carbon prepared from coconuts shells using FTIR, XRD and SEM techniques. Jurnal Ilmiah Pendidikan Fisika Al-Biruni, 7, 1, 33-39. https://doi.org/10.24042/jipfalbiruni.v7i1.2459

Bani, M., Santjojo, D.H., 2013. Pengaruh suhu reaksi reduksi terhadap pemurnian karbon berbahan dasar tempurung kelapa. Natural B. 2, 2, 159-163.

Budi, E., 2017. Pemanfaatan briket arang tempurung kelapa sebagai sumber energi alternatif. Sarwahita 14, 81-84. https://doi.org/10.21009/sarwahita.141.10

Hidayat, Y., Nurcahyo, I., Rahmawati, F., Dwi N, K., Lestari, W.W., 2020. Penambahan karakter luas permukaan dan ukuran pori arang sebagai upaya diversifikasi produk arang dari tempurung kelapa pada CV. Solo Button. J. Kewirausahaan Dan Bisnis 24, 94. https://doi.org/10.20961/jkb.v24i14.37724

Jamilatun, S., Salamah, S., Isparulita, I.D., 2016. Karakteristik arang aktif dari tempurung kelapa dengan pengaktivasi $\mathrm{H}_{2} \mathrm{SO}_{4}$ variasi suhu dan waktu. Chem. J. Tek. Kim. 2, 13. https://doi.org/ 10.26555/chemica.v2i1.4562

Jamilatun, S., Setyawan, M., 2014. Pembuatan arang aktif dari tempurung kelapa dan aplikasinya untuk penjernihan asap cair. Spektrum Ind. 12, 73. https://doi.org/10.12928/si.v12i1.1651

Kementan RI, 2019. Produksi kelapa menurut provinsi di Indonesia, 2017-2021. url https://www.pertanian. go.id/home/index.php?show=repo\&filenum $=215$

Kong, J., Gu, R., Yuan, J., Liu, W., Wu, J., Fei, Z., Yue, Q., 2018. Adsorption behavior of $\mathrm{Ni}(\mathrm{II})$ onto activated carbons from hide waste and high-pressure steaming hide waste. Ecotoxicol. Environ. Saf. 156, 294-300. https://doi.org/10.1016/j.ecoenv.2018. 03.017

Kurniawan, R., Lutfi, M., 2014. Karakterisasi luas permukaan bet (Braunanear, Emmelt Dan Teller) karbon aktif dari tempurung kelapa dan tandan kosong kelapa sawit dengan aktivasi asam fosfat 2, 6 .

Laos, L.E., Selan, A., 2016. Pemanfaatan kulit singkong sebagai bahan baku karbon aktif. J. I. Pend. Fis., 1, 1, 32-36.

Lestari, R.S.D., Sari, D.K., Rosmadiana, A., Dwipermata, B., 2016. Pembuatan dan karaktersasi karbon aktif tempurung kelapa dengan aktivator asam fosfat serta aplikasinya pada pemurnian minyak goreng bekas. Tek. J. Sains dan Teknol. 12, 419. https://doi.org/10.36055/tjst.v12i2.6607

Nustini, Y., Allwar, A., 2019. Pemanfaatan limbah tempurung kelapa menjadi arang tempurung kelapa dan granular karbon aktif guna meningkatkan 
kesejahteraan Desa Watuduwur, Bruno, Kabupaten Purworejo 04, 10.

Packialakshmi, S., Anuradha, B., Nagamani, K., Sarala Devi, J., Sujatha, S., 2021. Treatment of industrial wastewater using coconut shell based activated carbon. mater. Today Proc. S2214785321034738. https://doi.org/10.1016/j.matpr.2021.04.548

Rohmah, P.M., Redjeki, A.S., 2014. Pengaruh waktu karbonisasi pada pembuatan karbon aktif berbahan baku sekam padi dengan aktivator $\mathrm{KOH} 3,9$.

Siahaan, S., Hutapea, M., Hasibuan, R., 2013. Penentuan kondisi optimum suhu dan waktu karbonisasi pada pembuatan arang dari sekam padi. J. Tek. Kim. Usu 2, 26-30. https://doi.org/10.32734/jtk.v2i1.1423

Zohri, A.S., Sari, N.H., Sujita, S., 2013. Pemanfaatan serbuk tempurung kelapa pada komposit $\mathrm{Al}_{2} \mathrm{O}_{3}$ epoxy. Din. Tek. Mesin 3. https://doi.org/ 10.29303/d.v3i2.75

Wibowo, S., Syafi, W., Pari, G.P., 2011. Karakterisasi permukaan arang aktif tempurung biji nyamplung.
Makara Technol. Ser. 15. https://doi.org/ 10.7454/mst.v15i1.852

Widiyastuti, W., Fahrudin Rois, M., Suari, N.M.I.P., Setyawan, H., 2020. Activated carbon nano fibers derived from coconut shell charcoal for dye removal application. Adv. Powder Technol. 31, 3267-3273. https://doi.org/10.1016/j.apt.2020.06.012

Zamhari, M., Junaidi, R., Rachmatika, N., Oktarina, A., 2021. Pembuatan katalis berbasis karbon aktif dari tempurung kelapa (Cocos Nucifera) diimpregnasi $\mathrm{KOH}$ pada reaksi transesterifikasi sintesis biodiesel $12,9$.

Zhou, J., Luo, A., \& Zhao, Y. (2018). Preparation and characterisation of activated carbon from waste tea by physical activation using steam. Journal of the Air \& Waste Management Association, 68, 12, 1269$1277 . \quad$ https://doi.org/10.1080/10962247.2018. 1460282 